\title{
Psychiatric Hospitals and Older People: Status Quo or Making Changes?
}

Huge and forbidding, Friern Hospital, where the AEGIS (Aid for the Elderly in Government Institutions) campaign began in 1965, had 2,250 beds and an unwelcoming, dimly lit corridor more than one third of a mile long, which connected most of the wards. The corridor lights could go off unexpectedly as Friern's electricity supply needed upgrading: ${ }^{1}$ 'it would not do to ask a nervous person to visit' said Barbara Robb (1967, p. 78). A male junior doctor recollected:

You were a bit fearful walking down the corridor. It was the most peculiar experience... you would see a furtive head looking quietly out of a little nook or cranny, which was actually an entrance to a ward ... so you would wonder what was going to happen to you. You had to be rather bold.

While working at Friern in 1964-1965, that doctor hardly mentioned to his colleagues in other hospitals that he was employed there: 'I think it was regarded as being rather a tainted claim to fame.... I don't think my peers were aware of it, to be honest.... It wasn't something you wanted to crow about or boast about amongst other trainees or amongst your seniors. ${ }^{2}$

Friern Hospital was originally named Colney Hatch Asylum. It opened in 1851, the largest and most modern institution of its kind in Europe (Hunter and Macalpine 1974, p. 11). It was one of a network of county asylums built in the mid-nineteenth century, based on humanitarian principles and optimism by the 'mad doctors' that they would find treatments

(C) The Author(s) 2017

C. Hilton, Improving Psychiatric Care for Older People, Mental Health in Historical Perspective, DOI 10.1007/978-3-319-54813-5_2 
for insanity. Alongside demographic changes of an increasing population, tolerance of bizarre behaviour lessened, particularly in more urbanised and regulated environments, and demands for beds rose. Hopes of effective treatment diminished and a custodial approach became common (Rogers and Pilgrim 1996, pp. 46-50). In 1884 the Lunacy Commission (renamed Board of Control in 1913), the public authority overseeing the asylums, commented that older people at Colney Hatch occupied disproportionately more beds than would be expected from their number in the population, and that 'special provision for the aged' was essential to reverse the trend (Hunter and Macalpine 1974, p. 62). The Commissioners observed the pattern elsewhere and in 1897 reported their concern to the responsible authorities (Lewis 1946, p. 151). The government ignored the worsening situation, fearing the economic costs of providing for more older people. The medical profession lacked interest, and there was no public pressure to make changes (Hilton 2016, p. 20). By 1963, people over age sixty-five made up 12 percent of the population but occupied 39 percent of psychiatric hospital beds $(47,782$ of 123,744 ), and startlingly, women over age seventy-five (making up 5 percent of the female population) occupied 25 percent of all female beds in those hospitals (Brooke 1967, p. 4). ${ }^{3}$

The most progressive psychiatric hospitals functioned therapeutically despite antiquated buildings. During the 1950s and early 1960s, they were led by dynamic psychiatrist 'medical superintendents', such as Bertram Mandelbrote at Littlemore (Oxford), Denis Martin at Claybury (Essex) (Martin 1962), and Russell Barton at Severalls (Colchester) (Jolley 2003). ${ }^{4}$ Other hospitals, such as Friern, lacked a forceful leadership. ${ }^{5}$ The medical superintendent, together with the senior nurses and administrative staff of the hospitals-usually a matron, chief male nurse and hospital secretary-were expected to liaise with their voluntary Hospital Management Committee (HMC). The Minister of Health, through the Regional Hospital Boards (RHBs), appointed HMC members, based on their 'knowledge and experience', without defining what that meant (Ministry of Health (MoH) 1966, p. 6). HMC members were usually highly committed and well intentioned, ${ }^{6}$ and the Ministry delegated a high level of financial and organisational responsibility to them $(\mathrm{MoH} 1966$, p. iii). The National Association for Mental Health (NAMH), however, regarded HMCs as 'too often ill-qualified-by reason of their age, their backgrounds, the rigidity of their outlook, or their sheer ignorance and inexperience of the matters with which they must deal'. The Patients 
Association (PA) had other concerns about the effects of delegation to RHBs and HMCs because it resulted in lack of ministerial control over the hospitals, to the extent that 'guidance' or 'advice' that the Ministry sent to RHBs was usually ignored. ${ }^{8}$

HMCs faced numerous challenges in their hospitals, including ensuring adequate staffing and standards of care, managing overcrowding, and maintaining and modernising buildings. When the Mental Health Act (MHA) 1959 abolished the Board of Control, responsibility for inspections and maintaining standards passed to HMCs who would 'visit' their own hospitals. HMCs received little guidance about how to determine quality. A senior member of the hospital staff usually accompanied them during their visits, which discouraged patients and most staff from voicing concerns. HMC visitors focussed on the physical environment rather than what went on in it. Good interior decor led to glowing reports when psychological and social care was atrocious (Barton 1959, p. 48).

To contextualise the situation that so disturbed Barbara Robb when she visited Amy Gibbs in 1965, it is necessary to understand the interactions between older people and the hospital wards and community services, research and innovation about their needs and the government's standpoint on service provision. During the period from the early 1940s until the mid-1960s, these strands had no clear single chronology and only limited overlap, so in this chapter they are explored thematically. Research on diagnosis and treatment of mental illnesses in older people, for example, had little effect on clinical practice, and government initiatives for older people did little to implement the research findings or remedy overcrowding in back wards. The relevant developments during the same period at Friern are described at the end of the chapter.

\section{The Psychiatric Hospital Wards}

In the mid-twentieth century, some patients with mental illnesses were discharged from hospital in an improved state, but there were, and are, always some who require on-going care. Proportions of short- and longstay patients varied, depending on a combination of factors, which Kathleen Jones (1993, pp. 150-158) optimistically alluded to, in the 1950s and 1960s, as the social, pharmacological and legislative 'revolutions' of psychiatric care. Social developments included day hospitals, therapeutic communities and the 'open door movement' (p. 151). Pharmacological treatments, research and greater understanding about 
mental illness helped shape medical practice and enabled more people to be discharged. New legislation - the MHA 1959-facilitated and encouraged, but did not mandate, more liberal and community approaches. Another factor noted around the same time was the psychological damage resulting from long-stay custodial care. In 1959, Barton coined the term institutional neurosis to describe this. Hallmarks of institutional neurosis comprised apathy, loss of interest, submissiveness and social withdrawal. Barton identified seven causes: ward atmosphere; bossiness of staff; medication; enforced idleness; loss of personal friends, possessions and life events; loss of contact with the outside world; and loss of prospects outside the institution (Barton 1959, p. 17). He did not claim to have introduced a new neurotic illness, despite the name he gave it, but aimed to use his observations as a means to improving care (Jones and Fowles 1984, pp. 71-78).

In 1961, Erving Goffman, a sociologist in the United States, wrote about 'total institutions', including 'stripping', a dehumanising removal of all personal belongings as part of the process of complying with group living on admission to an institution. Uniform haircuts, enforced bathing or showering on entry and other demeaning practices, accompanied stripping. Officials could rationalise the practices, such as being for safety or hygiene, but they cumulatively destroyed individuality and ensured compliance in an institution segregated from the outside world. Compliance, by staff and 'inmates', was key to managing large numbers in a limited space with inadequate resources, as in prisons, concentration camps and custodial back wards (Goffman 1961, pp. 8, 119-220).

Psychiatrists and nurses in the hospitals often held unhelpful attitudes about their older patients, with low expectations about improving their health. In 1952, three well-regarded and experienced psychiatrists suggested:

we must be practical and temper our remedies to the gravity of the situation. It is more economical... to treat-say-60 patients in two wards, than the same number in three wards. We are forced... to overcrowd in the mental hospitals, and senile patients have proved to be the patients least affected by this (Cook et al. 1952, p. 382).

These psychiatrists did not explain how they assessed older people to be the 'least affected', but older people characteristically stoically accepted the care they received and the restrictions placed on them in an institution. 
The psychiatrists also did not mention how they ascertained that their patients were 'senile', raising the possibility that some were apathetic associated with undiagnosed depressive illness that could have been actively treated leading to discharge. They stated that they did not advocate a lower standard of care for older people, although it is impossible to see how their proposal to overcrowd wards could be interpreted otherwise.

Nurses on psychiatric wards mainly dealt with physical aspects of care, with a focus on neatness rather than therapy. For older patients they typically provided passive physical care and, fearful of reprimand, would overprotect their patients, such as wheeling them in a chair rather than allowing them to walk unsteadily, and other restrictions that undermined their independence (Whitehead 1970, pp. 26-29). They also removed patients' belongings, such as spectacles, to avoid them being lost or broken (Townsend 1973, pp. 132-135), concerning themselves with the loss of the objects for which they might be reprimanded, rather than on the benefits to the patient. In 1957, an enlightened textbook by Annie Altschul (a psychiatric and general trained nurse, later professor of nursing in Edinburgh) taught about encouraging older patients to lead fulfilling lives either within the hospital or aiming for discharge. Altschul's chapter on 'habit training' optimistically tackled rehabilitating demented patients who had lost skills due to being nursed in bed. She warned that nurses must 'never... allow patients to deteriorate to the degree to which they did in the past' (Altschul 1957, pp. 131-150, 145). Her teaching was radical in the 1950s: modern geriatric nursing became a compulsory component of training only in 1979 to comply with European Union requirements (Norton 1956, 1988, p. 34).

In understaffed wards, nurses often worked under pressure to complete the practical tasks delegated to them, and time-saving regimes could result in undignified care. Nurses interviewed in Jane Brooks' oral history study recollected lack of privacy, 'open bed-panning' (without screens between beds, visible to all on the ward), and the feeling of nursing a 'body' without being aware of the 'person' (Brooks 2009). Tommy Dickinson (2015, p. 114), in his study of 'mental nurses' in mid-twentieth-century psychiatric hospitals, commented on other harmful practices, including physical force and 'production line' bathing, where several people were bathed speedily at one time in a communal bathroom. One nurse he interviewed told him that 'because it was the norm you didn't question it' (Dickinson 2015, p. 110). The issue of communal bathing is worthy of 
discussion because it highlights grey areas encountered when deciding whether practices were acceptable or degrading. ${ }^{9}$ For standards of institutional care to be humane, they should be appropriate to the age, gender, physical, psychological and cultural needs of the individual. This necessitates modelling them on accepted practices outside the institution at the same time. In their own homes, older people usually bathed in private. Based on their practices before admission, older frail people, some of whom might be embarrassingly soiled due to incontinence, would have likely found the rushed process of communal production line bathing degrading. However, in some other contexts shared bathing was socially acceptable, such as for sports teams, creating a degree of subjectivity. Although some practices were categorically unjust, when techniques acceptable to staff but not to patients passed unchallenged, and were condoned by seniors, they became established as standard care.

Changing practice away from custodial methods towards rehabilitation was difficult to achieve. A cultural conservatism existed in many isolated, inward-looking psychiatric hospitals, which made introducing new practices difficult (Carse et al. 1958). A charge nurse who was previously a miner demonstrated this when he likened his hospital to 'a close knit mining community where relationships are very strong'. ${ }^{10}$ In such communities, established traditions and practices may be resistant to criticism and slow to change. In addition, after the Second World War, mental nursing was an attractive occupation for demobilised soldiers, especially those who felt comfortable in a conforming, hierarchical organisational structure (Nolan 1995, p. 13). Thus in some hospitals, almost military hierarchies, consisting of the incontestable and fear-provoking senior nurses plus many inadequately trained staff, reinforced regimented obeying of instructions, inflexibility and task-driven rather than individually focused nursing practices. Patients who conformed to rules were easier to manage and less labour intensive than individuals with personalised programmes of treatment or rehabilitation, thus the rigid system helped maintain a custodial approach. This corroborates the views of one psychiatrist in the 1960s, who recollected some ward-level obstacles to change, when interviewed in 2016:

So far as the charge nurses were concerned,... [wards] were run by the nurses, they belonged to the nurses, the patients belonged to the nurses, and they felt they were their property, and they wanted people who were reasonably easy to look after, because that made life a lot easier. ${ }^{11}$ 
Dickinson's analysis revealed punitive aspects of the rigid staff hierarchy: staff disobedience, complaints or questioning of practices, even if trying to introduce more therapeutic regimes, could be, and was, punished by instant dismissal (DHSS 1971, p. 21; Dickinson 2015, pp. 112, 179-199). Other penalties included banishing a nurse to a less prestigious or 'punishment' ward, often one caring for the most impaired older patients (Dickinson 2015, p. 114; Norton 1988, pp. 25-27). Former staff recalled seniors using underhand bullying tactics to 'get rid of oppositional people' or 'make the complainant see the error of his ways' (Dickinson 2015, pp. 183, 185). Most nurses accepted their role, to carry out, uncritically, whatever medical staff or their nursing superiors prescribed. A few took subversive action and maintained their careers, but the overall pattern was of passive obedience (Dickinson 2015, pp. 179199 ; Brooks 2009, p. 2768). According to Barton, a regimented approach could not fully succeed as 'kindness, pleasantness, sympathy and forbearance cannot be commanded by giving orders or passing resolutions' (Barton 1967, p. x). Nurse Bill Kirkpatrick (1967, pp. 52, 55) noted that the problem was compounded when the hospital leadership did not fully understand the challenges of nursing older people and showed lack of interest towards patients and staff on the back wards, which contributed to nurses feeling unwanted. He wrote, 'anyone who feels unwanted becomes apathetic towards all those in his care, to say the least'(p. 52).

Social factors also influenced nurses' approach to criticising. They often had a long-term relationship with their hospital. Their relatives worked there and they lived, with their families, in tied accommodation. Antagonising the hospital authorities could risk losing job, home and family life, and according to Abel-Smith, some feared that their children would be beaten up by members of staff against whom they lodged complaints. ${ }^{12}$ Junior doctors, as the nurses, had cultural norms concerning challenging their superiors. They could also be victimised if they criticised. ${ }^{13}$ However, junior doctors often had short-term contracts, lived outside the hospital and, although they feared a detrimental reference for their next post, were in less personal jeopardy if they spoke up.

Comments made to external independent researchers were likely to have been more honest. In a study by social scientists Kathleen Jones and Roy Sidebotham (1958-1959), student nurses described their experiences in three mental hospitals. On one ward in a large hospital the nurses' role was 'chiefly that of custodian and domestic help' (Jones and Sidebotham 1962, p. 204). Nurses were 'full of genuine care and interest' 
for their patients but did not seem to understand the important part they could play in helping them with social activities. Patients who exhibited difficult behaviours were treated like naughty children and the ward lacked a 'fundamental attitude of respect towards patients, that they were adult human beings' (p. 204). Nurses feared the sister's wrath if they sat and talked to a patient, or attempted psychological and social therapeutic interventions, because it was considered 'slacking' (p. 203). By contrast, in another hospital in the study, the ward doors were unlocked, and nurses 'acted as friend and companion rather than as warder' and helped the patients to preserve their independence and autonomy (p. 198).

By the early 1950s, many mental hospitals implemented successful open-door policies. Jones referred to this as part of the 'social revolution' of psychiatric treatment, alongside industrial therapy, therapeutic communities, social clubs for patients and other 'normal' activities (Jones 1993, pp. 150-154). Mandelbrote (1964, pp. 268-270) evaluated an open-door policy in his hospital. He found that a therapeutic ward environment that gave patients greater autonomy meant that 'locked doors and physical barriers against escape were no longer necessary.' Incontinence, incidents requiring seclusion, and destructive and impulsive behaviours also declined, to about one fifth, one year after introducing the policy, with minimal increase in absconding, no increase in serious injuries, and reduced use of night sedation (pp. 272-273). By contrast, Friern maintained a policy of locked wards into the 1960s (MoH 1968a, p. 22).

Hospitals usually began to implement liberal policies on wards with patients perceived as most likely to benefit. This strategy was logical because success would build staff confidence and therefore help alter a large institution that was resistant to change. Thus wards for younger patients became hotbeds of innovation, with active treatment and rehabilitation (Martin 1962). Patients perceived as difficult or less likely to benefit, such as older people, were left until last for experimental approaches (Barham 1997, p. 22). This created a two-tier system within the institution. Psychiatrist Brice Pitt (1968, p. 29) wrote:

Claybury's present reputation rests largely on these units. There are, however, snags, and instead of the whole hospital going on to develop similarly, a sizable split has appeared between these wards where the action is, which get lots of visitors and publicity, and the 'Chronic Hospital' which feels more out of things than in the bad old days when there was little treatment. 
Whether the Ministry understood the pitfalls of two-tiers is unclear (Jones and Sidebotham 1962, p. 62) but it added to staff tensions in many hospitals, including Friern. ${ }^{14}$ In 1958, Friern opened Halliwick, a separate treatment and rehabilitation hospital in the grounds. It was better staffed than the main hospital and there were no long-stay patients. Only 5 percent of admissions were older than sixty-five years of age, compared to 23 percent in the main hospital. ${ }^{15}$ Staff in the main hospital perceived Halliwick as attracting the 'cream' of the staff, the most 'rewarding' patients and better resources. ${ }^{16}$ Few staff crossed the metaphorical fence between them. ${ }^{17}$ When Barbara discussed the two-tier system with Richard Crossman in 1969, she told him that she declined Friern's suggestion that she should visit Halliwick because she had received reports about it from the family of a peer's wife. Crossman responded that 'it would probably be impossible to get into Halliwick unless you are at least a peer's wife' and it staggered him 'that this could be allowed under socialism'. ${ }^{18}$

Secondary historical sources rarely mention complications associated with the two-tiers. Progress towards community care is celebrated, while those patients who were most disabled and mainly older remained in the hospitals as late as the 1990s and are hardly mentioned. Peter Barham wrote about the resettlement of long-stay patients to the community, mentioning one study about the most mentally disabled and hardest to discharge long-stay patients, which, curiously, excluded people with dementia (Barham 1997, p. 22). This hardly clarified the issues as they related to older people. Antipsychiatry, which emphasised personal autonomy and criticised the way society defined mental illness through social, political and legal means, also affected hospital practice in the 1960s. It particularly encouraged rehabilitation programmes and more liberal care regimes, but it too overlooked older people. A handful of antipsychiatry writers, psychiatrists among them, advocated primarily for younger mentally ill people. For example, RD Laing and Aaron Esterson (1964, pp. 31-264) described patients under forty years of age, mainly with schizophrenia, and Goffman (1961, 1963) hardly mentioned older people in his monographs on discrimination and institutionalisation despite their increasing presence in psychiatric hospitals. Any influence of antipsychiatry on services for older people was incidental to its main objectives.

Social scientists documented, and attempted to improve, care for older people. In Townsend's (1965) chapter 'Prisoners of neglect', he noted that levels of function of many older people on back wards were similar to those in local authority care homes, suggesting that they did not need 
specific psychiatric hospital placement. Townsend also reported boredom, uniform haircuts and disrespect for personal identity on the back wards. Some older people on these wards were very lucid, but had hearing, visual or speech impediments, and staff labelled them as mentally impaired. Many lacked aids that could enable communication and improve function. Deplorably,

A considerable number possess capacities and skills which are held in check or even stultified. Staff sometimes do not recognise their patients' abilities, though more commonly they do not have time to cater for them (Townsend 1965, p. 229).

Many older people were trapped in psychiatric hospitals because of lack of more appropriate alternatives, including geriatric medical wards, domiciliary support and residential care homes. With older people's needs straddling health and social care, the authorities argued about which of them should take financial responsibility for providing support, rather than ensure the most appropriate use of resources (Means and Smith 1985, p. 173).

Townsend criticised the authorities for hiding the worst aspects of the psychiatric hospitals when, in his view, the defects were remediable. Although hospital conditions for older people were by no means uniform, his negative experiences lingered:

It is not just the appearance, the coarseness to the touch, the noise or the impenetrable silence but the smell of neglect that remains imprinted on the mind: the sweet but slightly rotting smell of an assortment of bewildered human beings who exist in claustrophobic proximity like wrinkling apples spaced fractionally apart in a dark cupboard (Townsend 1965, p. 135).

\section{Wards and Community: Getting the Balance Right}

Ward environments were often inadequate, but many domestic dwellings were also impoverished, especially in urban areas. Doctors visiting patients in Birmingham in 1949 described some homes as 'dark, infested slums' (Thomson 1950, pp. 930-931). A survey in Glasgow in the late 1950s, where housing was particularly bad, indicated that in spite of housing difficulties, almost all the old people we met had no desire to make a 
change and any suggestions to this end were usually met with hostility' (Thomson 1959, p. 447). Older people perceived the hospitals as institutions with the stigma of workhouses and asylums. Their own homes, though poor and lacking in facilities, were more than buildings. They contained personal possessions and memories that contributed to the occupier's sense of identity, security, self-esteem and perceived roles in their family and community (Macmillan 1960). Long-term hospital admission deprived older people of these assets, but their wishes were often not acknowledged. Wealthier older people could choose to stay in their own homes, but poorer people usually had no choice and little was done, such as through welfare schemes, to enable them to do so (Harvey 1965). Community welfare provision was insufficient in many places. John Welshman (1996 p. 89), in his study of public health and older people, concluded that stagnation, patchiness and haphazard local authority social care was common, associated with financial constraints, and that central government encouraged, rather than insisted, that services were provided.

According to psychiatrist Cecil Kidd (1962a, p. 457) younger people were admitted to hospital because they needed treatment for their illness, whereas older people were admitted because 'either they cannot be treated or cannot be tolerated at home' (italics in original). Thus for some older people assumed to have no hope of recovery, who could not be supported at home by their families and for whom no alternatives existed, psychiatric hospitals were 'dumping grounds' (Strabolgi 1965; DHSS 1972, pp. 2021). Assumptions about irreversible decline were associated with older people bypassing the hospital assessment wards and being admitted directly to long-stay psychiatric wards (Robinson 2009, pp. 9-10). This precluded thorough medical assessment, so remediable physical illness, which in older people could be masked by mental disturbance ('acute confusion' or 'delirium'), would remain undiagnosed and untreated. This relationship was known to general practitioners (GPs) in the 1950s: 'The noisy, restless, agitated old person will often die if moved to a mental hospital' (Batt 1949; Taylor 1954, p. 414).

Evidence accumulated from the 1940s about the need to support families caring for an older person to prevent them despairing and giving up, but little was done to remedy the situation (Rowntree 1947; Sheldon 1948). Families were often 'unreasonably willing' to provide care at home (Lowther and Williamson 1966, p. 1460) but a sudden deterioration in an older person's level of confusion 'nearly always precipitates a crisis in the patient's family' (Anderson 1956, p. 343), the final straw for a family 
lacking practical support and without emotional reserve to cope with additional stress. Townsend reiterated the need for more support for older people living alone, and for families caring for them, to prevent 'dumping' (Townsend 1962, pp. 106-108, 1965, p. 233).

GPs held the key to community medical and nursing resources and to hospital services. Stephen Taylor (later, Lord Taylor of Harlow), a physician, investigated thirty outstanding general practices, aiming to depict practice worthy of adoption elsewhere. Taylor noted diverse views about older people. Some GPs thought that, with time and patience, working with them could be rewarding. Others viewed them as 'difficult, and even unpleasant... often inarticulate, hard to get to know, and slow to respond' (Taylor 1954, p. 413). One husband and wife GP team, Cuthbert and Beatrice Watts, wrote gloomily that 'senile demensia' ( $s i c$ ) is common in the 'last decade of life', 'Nothing can be done for these unfortunate people' and older people 'can be most difficult and trying' (Watts and Watts 1952, pp. 140,145). Some GPs were aware of the need to support families, but others thought it best to advise them that providing care 'can only have an adverse effect on their own lives, without benefiting the patient's in the slightest', and because 'no additional help can be sufficient to make it bearable', admission to long-stay care was preferable (Gibson 1957, p. 111). Conveniently for GPs, this fitted with psychiatrists' views that their hospitals had an obligation to fulfil GPs' requests 'to admit the elderly dementing type of patients from the catchment area'. ${ }^{19}$ Psychiatrists genuinely tried to help older people by admitting them when they had nowhere else to go and no one to help them with the essentials of daily life, ${ }^{20}$ but neither GPs nor psychiatrists were keen to actively work with them (Watts and Watts 1952, p. 140). Tensions existed between GPs and the psychiatric hospitals, as David Enoch, a consultant psychiatrist at Shelton Hospital, Shrewsbury, described in the early 1960s:

GPs used to ring us up and say: 'An old bird is on the way to you.' Sometimes we were lucky if we even had a message at all! When we went round in the week we were told that there were three people over 80 that had been 'pushed in.' The matron and the chief male nurse just had to find a bed. These patients merely appeared. I have great respect for the local authority and those trying to deal with the chronic sick - but Shelton was the 'dumping ground' for this county. I think the hospital deserves a medal. ${ }^{21}$ 
Webster noted that GPs perpetuated adverse assumptions of the irreversibility of the problems of old age (Webster 1991a, p. 181). GPs' comments suggested lack of motivation to attempt to improve community psychiatric care for older people, or lack of understanding that it might be possible. How widespread those attitudes were is unclear, but they indicate the depth of pessimism that needed to be overcome to provide psychiatric care in the community.

\section{Research and Innovation: Challenging Medical Doctrine About Older People}

In the 1940s, some psychiatrists in Britain began to challenge the medical profession's clinical negativity towards mentally unwell older people. One surveyed his older patients, concluding that their mental illnesses were not inevitable, that depressive illness could be distinguished from dementia and that interventions could help (Post 1944). Successful treatment of depressed older people using the new electroconvulsive therapy (ECT) (Mayer-Gross 1945, p. 101) and evidence that social interventions could prevent admission and enable discharge of confused older people (Lewis and Goldschmidt 1943) surprised the clinicians.

In 1950, the Bethlem and Maudsley Hospital in South London was the only mental hospital in the country to have a psychiatrist working specifically with older people-Felix Post. He aimed to diagnose their illnesses accurately and actively to treat depression, schizophrenia and other disorders. He achieved good results (Hilton 2007). Post's work was reinforced by Martin Roth's meticulous study (1955), which demonstrated conclusively that the practice of labelling all 'confused' older people as having irreversible 'senile dementia' was obsolete. He identified five psychiatric disorders in its place, of which delirium, depressive illness and 'late paraphrenia'22 were particularly important because they were often reversible. The medical profession paid little attention to Post's and Roth's findings, which challenged time-honoured teaching and the common stereotypes of old age (Robinson 2009, p. 8; World Health Organisation 1959, p. 10). Failing to take heed of their discoveries prolonged unnecessary suffering. Psychiatrist Anthony 'Tony' Whitehead (1974), commented:

Old people may spend their last years in dreadful misery because severe depression has been wrongly diagnosed as senile decay.... If you are anxious and depressed, and more and more people start treating you as if you were a 
difficult child, and you are finally incarcerated in a ward full of other elderly people who are being treated in the same way, it is likely that in time you will give up and take on the role of not just a child, but a baby.

The new ideas about older people's mental illness emerged in tandem with geriatric medicine (Warren 1943). Geriatric medicine had a slow start, and in the 1950s, geriatricians were few and far between. In general hospitals without them, consultant physicians often resisted admitting older people because they feared that these patients' illnesses were chronic, and that they would remain in hospital and 'block beds' (Howell 1951, p. 505). Brice Pitt recollected in an oral history interview about his experience as a junior doctor in the 1950s:

Even my very good mentor had the attitude that a good registrar did not admit an old person. A bad registrar did...

The hospital ... was like a castle, a good registrar would fend off the elderly, as those who got in were bound to stay, bound to be dumped by their family. ${ }^{23}$

The general hospital consultants held disproportionate power in local hospital hierarchies, so a GP's request for admission to their hospital could be rejected on the basis of the patient's age, before the hospital made a clinical assessment. Admission to a psychiatric hospital was often the only alternative.

Sometimes geriatricians, notably, Lionel Cosin in Oxford, attempted to treat and support older people suffering from mental illness (Anon. 1954). Cosin's innovations included a day hospital plus respite beds to help families undertaking long-term care. However, the local psychiatrists' priorities mainly concerned younger patients, and they were often unsupportive of him. ${ }^{24}$ In Cosin's view, and that of other eminent geriatricians, ${ }^{25}$ psychiatrists were clinically inept with older people, an attitude unlikely to promote collaboration.

Geriatricians had plenty to do in general hospitals and rarely worked in mental hospitals, and most psychiatrists had little enthusiasm to implement the principles of geriatric medicine (Denham 2004, p. 357). One nurse in 1967 gave her view of the attitude of many psychiatrists towards older people: 'Oh! They're just Anno Domini, any old thing will do.'26 This might have allowed interested psychiatrists carte blanche to work with older people. However, such freedom was moderated by complex 
interactions in the psychiatric hospitals, such as weighting the salaries of some senior hospital staff by the number of beds standing, ${ }^{27}$ which would not incentivise rehabilitation and discharge. Nevertheless, in 1958, psychiatrist Ronald 'Sam' Robinson established a proactive, assessment and rehabilitation-based psychiatric service specifically for older people, at Crichton Royal Hospital, Scotland, which gradually inspired practice south of the border (Bergmann 2009; Gulland 2014). It comprised outpatient, domiciliary, in-patient (including respite) and community services. Sam Robinson incorporated principles of geriatric medicine into his psychiatric wards, which contrasted with practices observed in the 1960s at Friern and in other hospitals. He took into account, for example, that incontinence was unintentional and was associated with toilet facilities at a distance and poor mobility and that regular toileting minimised daytime incontinence, even for people with dementia. At Crichton Royal, good-quality flooring and shoes encouraged mobility and minimised falls, occupational therapy reduced agitation and 'wandering', men and women shared the same wards and wore their own clothes, and staff found that respecting the patients' dignity and wishes gained their cooperation. Sam Robinson achieved high discharge rates compared to other hospitals (Robinson 1965), demonstrating what could be achieved, even for incurable disorders such as dementia. Unfortunately, the Ministry of Health oversaw the NHS only in England and Wales, so Sam Robinson's scheme was outside their watch. Evidence is lacking that they sought to find out more about it when results were published.

In 1961, inspired by the scheme at Crichton Royal, Barton and Whitehead, introduced similar plans at Severalls Hospital. ${ }^{28}$ Severalls' service operated on the principle that older people should remain in their own homes as long as possible and that admission was primarily short-term for active treatment. The total number of beds used by older in-patients fell by a quarter (374 to 296) over sixteen months, despite more brief admissions for assessment and treatment (Whitehead 1965). Barton and Whitehead helped staff overcome deeply embedded unhelpful attitudes towards older people, including lack of interest, infantilising approaches to dependency (such as referring to patients in cot beds as 'babies') and harsh undignified criticism ('You filthy old thing. I shall smack you if you do that again') (Whitehead 1970, p. 28). The Ministry attributed the scheme's success to local circumstances rather than envisioning wider application and encouraging its adoption elsewhere (Brothwood 1971, p. 110). Barton and Whitehead also encouraged older 
people to have a say in their care, acknowledging that 'doctors and nurses do not necessarily know best' (Whitehead 1970, p. 35). This concurred with Cohen's (1964) observations, that the paternalistic style of the NHS had not yet adopted values centred on patient autonomy and individuality.

Several well-constructed epidemiological studies in the early 1960s indicated scope to improve the mental health of older people, avoid admission to hospital and alleviate the stresses on families caring for them (Kay et al. 1957, 1964a, 1964b). Recommendations included health and welfare services complementing the work of GPs, housing schemes for older people and appropriate social and recreational facilities. Registers of vulnerable older people could facilitate assessments to help detect mental and physical disorders at an early stage and provide treatment and support (Kay et al. 1964 b, p. 681). This was important because GPs were often unaware of disabilities, depression and dementia. Although GPs' expectations and knowledge were crucial to awareness, other contributory factors included older people and their families not reporting ailments to their GPs, and, linked to age stereotypes, attributing symptoms to age rather than treatable illness and assuming that nothing could be done to help. Thus underdiagnosis and treatment was associated with avoidable and neglected illness that contributed to crises and emergency hospital admissions (Williamson et al. 1964). Post, Roth, Cosin, Sam Robinson, Whitehead and Barton demonstrated what could be achieved, but they were a minority. More common was the fear of the 'looming geriatric impasse' (Kingston 1963) and the assumption, based on demographic change and increasing demand, that it would be impossible to prevent overcrowding the hospitals. To achieve widespread active treatment and rehabilitation for older people required: a culture shift among GPs, doctors and other staff in psychiatric and general hospitals; higher expectations by the public of what could be achieved; and support from central government.

\section{The Government's STAndpoint}

William Beveridge's (1942, p. 92) proposals for the welfare state included older people, but lacked enthusiasm, precision or a sense of priority about them. Nevertheless, Minister of Health Aneurin Bevan stated optimistically in the House of Commons in 1947: 'The workhouse is to go.' In their place, a five-year goal was set to achieve better domiciliary support to enable older people to remain longer in their own homes, and to provide small attractive community residential units each accommodating twenty 
to thirty people. ${ }^{29}$ The leadership did not enforce provision, a pattern of failed implementation for older people's services recognised before the NHS (Webster 1991a, p. 166). Webster (p. 188) noted that 'the elderly bore their disappointment with dignity, and general public indignation was slow to materialise.' Some doctors and administrative authorities blamed older people for the inadequacy of hospital and community services: beds were 'blocked by cured cases' (MoH 1957, p. 27), reflecting the 'burden of those old people' (Bickford 1955). Postwar austerity complicated planning, and demographic predictions created unease about the effect of older people on the economy and how the country would provide for them (Political and Economic Planning 1948). Ominous speculations surpassed the optimistic (Thane 1990, p. 292). The Royal Commission on Population (1949, p. 113) commented: 'It is the fact that (with some exceptions) the old consume without producing which differentiates them from the active population and makes of them a factor reducing the average standard of living of the community.' Little account was taken of many retired people who continued to contribute to society, by doing voluntary work and supporting their families, friends and neighbours, rather than requiring care.

The complex needs of unwell older people and the families who supported them, required planning and coordination across several professions and at all levels of health and social services administration. This received much discussion during the 1940s, such as by the British Medical Association (BMA) and the NHS mental health specialist advisory committee (Webster 1991b, p. 103). They helped shape two government circulars, Care of the Aged Suffering from Mental Infirmity and Treatment of the Elderly Chronic Sick (MoH 1950a, 1950b). The circulars recommended joint psychiatric-geriatric assessment schemes, but were noncommittal about funding and did not inspire or entice clinicians into the field. Joint schemes hardly materialised (Hilton 2014; Webster 1991a, p. 178). The titles of the circulars also revealed prevailing attitudes and expectations: passive 'care' for mental disorders compared to active 'treatment' for physical conditions. Assumptions about the need for passive care underpinned other proposals, such as by Donald Johnson, a medically qualified Conservative MP, who described day-care facilities, in a caring and thoughtful manner, as places where older people 'can be parked for two or three days a week'. ${ }^{30}$

The Board of Control expressed ambivalence about modernising mental health services to coincide with proposals for the NHS. Mental health 
legislation, it said, would need to change first, but that would require a review on the scale of a Royal Commission (Rogers and Pilgrim 1996, p. 65). A Cabinet memorandum in 1950 indicated that Bevan was uneasy about the mental hospitals: some 'are very near to a public scandal and we are lucky that they have not so far attracted more limelight and publicity'. ${ }^{31}$ Merrick Winn (1955) wrote in the Daily Express that most mental hospitals are 'a disgrace to a nation that calls itself civilised. They [nurses] are doing a magnificent job. But they often do it in conditions in which, had I not seen them, I would not have believed could exist in Britain.' With little public pressure or motivation by the Ministry to back improvements, poor standards persisted.

Postwar, health and social care provision for mental illness and for older people lagged behind other clinical services. Widespread excessively negative beliefs about chronicity, mental illness and old age and increasing demands on the NHS to provide highly technical investigations and treatment for acute physical illnesses, influenced government priorities. 'Cinderella' services became casualties of unremitting retrenchment in the 1950s and victims of broken promises, such as those made in election manifestos (Webster 1991a, p. 188). The UK was not alone in its deliberations, and the World Health Organisation (WHO 1959) issued pragmatic and far-sighted recommendations, influenced by Roth and Post, about mental health and older people. WHO's report, like others from reputable bodies (e.g., National Old People's Welfare Council 1958) created little professional, public or government interest or activity.

Speculative estimates of NHS costs dominated the government's and society's perceptions and discouraged spending (Rowntree 1947, p. 2; Mass Observation 1948). A Commons debate in 1954 estimated that it cost $£ 20$ a week to keep a patient in a teaching hospital and $£ 5$ a week in a mental hospital. Precise comparisons are difficult because of technological input and higher rates of acute physical illness in the former, but MPs did not raise the possibility that underspending in the mental hospitals might be detrimental. ${ }^{32}$ From the government's perspective, fitting more people into mental hospitals was economical. The same year, the title of another government report, The Economic and Financial Problems of the Provision for Old Age, hardly indicated impartiality (Phillips 1954). It focussed mainly on social needs but acknowledged that there were more admissions of older people to mental hospitals, often for social rather than health reasons (p. 74). It commented wishfully that 'their discharge rate will also increase in the near future' (p. 9), an 
assertion attributed to a recent report by the Board of Control. Evidence of that trend beginning was lacking, but citing it unquestioningly supported the committee's objective of minimising expenditure (Webster 1998, pp. 32-33). By contrast, the Guillebaud Report (MoH 1956) on the cost of the NHS indicated that, in the context of relatively stable NHS costs during the previous five years, additional funding for the needs of older people was affordable. It concluded with a much needed but unheeded message, to give older people 'their due priority in the allocation of additional resources' so that they are 'not overlooked amid the pressure of other competing needs' (p. 219). Guillebaud's report was unpalatable to the Conservative government, which expected it to provide evidence of excessive expenditure to enable tighter retrenchment of the NHS (Webster 1998, pp. 32-33).

The attitude that old age was a burden (rather than an achievement to be celebrated) reduced in the late 1950s (Thane 2000, pp. 475, 479). That linked to a persistently higher birth rate, the baby-boomers, some of whom were coming close to school-leaving age and could supplement the workforce to care for older people. This helped diminish the panic of the 'menace' of an ageing population (Thane 1990), but more younger people to care for them also lifted pressure from the government to improve services. With greater prosperity towards the late 1950 s, provision for older people changed little: in austerity everyone waited, and when the economy improved, older people waited until last.

At the end of the 1950s in England and Wales, about 300,000 people out of a population of 6.7 million of pensionable age ( 4.5 percent) lived in institutions of some sort. Approximately 60,000 lived in mental hospital back wards compared to 6,000 in modern purpose-built care homes. Former workhouses housed 30,000; 85,000 lived in geriatric wards of non-mental hospitals; and 120,000 lived in private, charitable and other communal establishments (Townsend 1962, pp. 44, 282). Unwell, frail older people were generally hidden in their homes or in institutions. They were invisible to most people and politically could be ignored. In 1961, the Ministry commented: 'One of the most urgent and complex problems is the care of mentally enfeebled old people.' It 'hoped' that more geriatric-psychiatric links would be forged ( $\mathrm{MoH}$ 1961, p. 98). That a problem could be described as 'urgent' and the response as 'hope' suggested lack of commitment to resolve it.

Broad plans for the NHS had potential to improve older people's provision. The MHA 1959 permitted modernisation of mental health 
services, such as relocating them from the psychiatric hospitals into the community and to district general hospitals (DGHs). In 1961, Minister of Health Enoch Powell optimistically addressed a NAMH conference (Powell 1961). He included the well-being of older people, the need to close the psychiatric hospitals and provide more community services and referred to the Hospital Plan (MoH 1962), a five-year national scheme for which fresh capital sums were allocated to build DGHs. Powell's Health and Welfare, a ten-year plan for community care, lacked dedicated resources or leadership ( $\mathrm{MoH} 1963)$. Government proposals failed to delineate lines of responsibility for funding, organising and integrating services within the NHS and between the NHS and social welfare authorities, as needed to provide for the most vulnerable older people (Means and Smith 1985, p. 167). Implementation was predictably slow, with lack of direction, and perhaps will, to fulfil commitments to enable older people to remain in their own homes as long as possible.

In 1963, a flurry of activity resulted from an alarming study that found that older people admitted to the wrong sort of hospital- to a psychiatric hospital when they needed physical healthcare and vice versa-had worse prognosis (Kidd 1962b). This rekindled the idea of joint psychiatricgeriatric assessment units. The Ministry drew on its broadly unimplemented guidance issued in $1950,{ }^{33}$ but evidence is lacking that it explored reasons for the failure of the earlier proposals. Dr Geoffrey Tooth, head of mental health at the Ministry was involved in planning for older people. Although he was not always effective (some psychiatrists nicknamed him 'the carious Tooth' ${ }^{34}$ ) his report in 1964 mentioned the need to prevent older people becoming mentally ill, such as with depression. For admission to psychiatric hospitals, he was aware of the clinical and social dangers:

a combination of superficial assessment and expediency leads to the filling of mental hospitals with old people whose physical needs are unrecognised and many of whom do not require in-patient treatment. The uprooting of such old people usually exacerbates their mental condition and, once in a mental hospital, it is exceedingly difficult to get them out. Added to which most mental hospitals lack the facilities for the assessment and treatment of the organic conditions that so often complicate or cause mental disorder. ${ }^{35}$

By 1964, every RHB in England except Oxford had some wards of over seventy people $(\mathrm{MoH} 1968 \mathrm{~b}, \mathrm{p} . \mathrm{11})$. A Ministry of Health report admitted that 'their sheer size makes it virtually impossible to provide a satisfactory 
standard of nursing care' (MoH 1968c, p. 52). A memorandum on older people in 1965 reiterated earlier recommendations, such as better collaboration for planning services and joint domiciliary assessment of patients by health and welfare staff to decide the most appropriate place for admission $(\mathrm{MoH} 1965$, p. 4). It did not mention the specific problems in psychiatric hospitals.

Townsend $(1962$, p. 7) regarded information about the care of older people in official reports as 'extraordinarily scanty and inept' and it 'did not speak much for the importance attached to these services by the central government.' He asked: 'Why, after 12 or 13 years' experience of post-war legislation, are the problems of the aged so insistent and disturbing and so far from amelioration, still less solution?' (Townsend 1961). No answer was forthcoming, but Webster (1991a, p. 166) offered the explanation that, alongside 'the mentally handicapped', as more people survived into old age, they were regarded negatively as part of the dependent 'growing tide of the unfit' about which little could be done.

By the mid-1960s, particularly for older people, underresourcing, understaffing, dilapidated buildings, and stagnation or good intentions hampered by professional and political paralysis, characterised the psychiatric hospitals. Despite evidence from a few places that improvements were possible, negativity towards unwell older people, and expectations that their demand on NHS resources would increase overwhelmingly, compounded the difficulties. In the competition for NHS resources, mentally unwell older people never reached top priority.

\section{InTroducing Friern Hospital}

Many of the broader concerns described earlier set the backdrop for the circumstances that shocked Barbara Robb in 1965 when she first visited Friern (Fig. 2.1). The rest of this chapter explores some of the issues at Friern directly pertinent to the AEGIS campaign and Sans Everything. It focusses on older people on the back wards, especially facilities, personal possessions, activities and staffing, but it draws on evidence about younger people or the entire hospital when necessary. Most information about Friern was obtained from HMC and RHB archives, but General Nursing Council (GNC) inspections, to licence the nurse-training school, provide an independent source. ${ }^{36}$ Another valuable autonomous perspective was given by Malcolm Campbell in an oral history interview in 2015 . He worked as a locum junior doctor at Friern from November 1964 until 


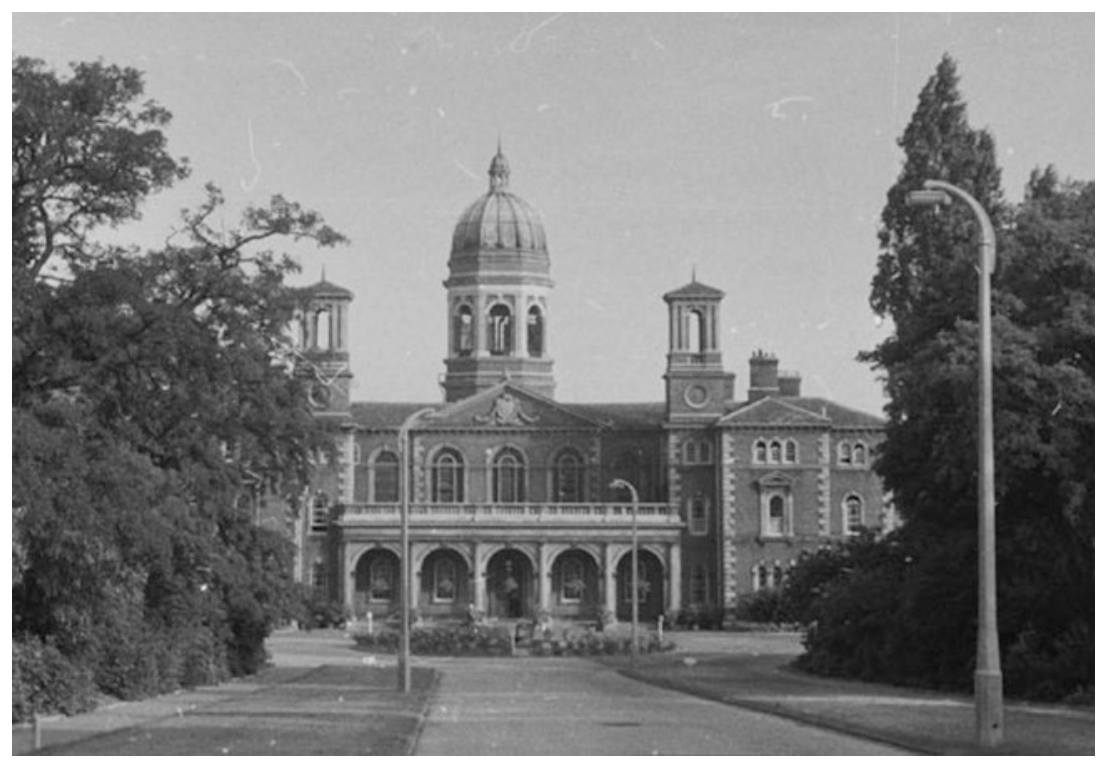

Fig 2.1 Friern Hospital, 1957. Photograph by Karl Ruge, reproduced courtesy of Friern Barnet and District Local History Society.

March 1965, between training posts in neurology, his chosen career. He worked in no other psychiatric hospitals so his recollections relate solely to Friern. His first impressions, vivid fifty years later, were of horror, 'Bedlam', or 'a dumping ground', which provided custodial care and where little medicine was practiced. ${ }^{37}$

The HMC faced numerous challenges. Second World War bombing destroyed five of the six villas in the grounds and damaged the main building, contributing significantly to overcrowding of patients and to Friern's dilapidated state. Friern was not alone in suffering in this way, but other hospitals affected, such as Claybury and the Bethlem, modernised their clinical work significantly more than Friern, despite structural limitations. ${ }^{38}$ In 1959, the GNC compared its findings to those in 1951, noting some environmental improvements, such as 1,500 new beds and 'plastic curtains giving a degree of privacy in bathrooms'. It also reported difficulties, including severe overcrowding and lack of storage space for patients' belongings so 
that 'day clothes are made into bundles at night' rather than being stored in bedside lockers. ${ }^{39}$ Lack of storage space meant lack of personal possessions, which could affect self-esteem, behaviour and rehabilitation (Barton 1959, p. 41). In 1963, the GNC made some positive comments, noting more lockers, pictures and plants, to make wards more home like. Many male patients had their own clothes, ${ }^{40}$ although female patients still wore hospital clothes, which Campbell described as 'very much a pre-war poor-house style.' Another positive factor was the opening of new facilities in the grounds the same year, for social activities and for patients to have refreshments with their visitors at visiting time. ${ }^{41}$

In 1964-1965 the HMC acknowledged overcrowding and lack of personal possessions. Some wards had up to 90 beds. On some wards, all patients had lockers, on others, none. ${ }^{42}$ To provide space for every patient to have a locker, 195 more beds would have to close. ${ }^{43}$ The HMC also recorded that about eight older people sustained fractures each month, mainly due to falls, more than in comparable psychiatric hospitals. Adequate nursing supervision and good-quality flooring and footwear could have prevented falls, ${ }^{44}$ as Sam Robinson (1965, pp. 188-190) found at Crichton Royal. Inspections revealed inadequate facilities for personal care and privacy, such as patients' toilet doors without locks. ${ }^{45}$ Ward E3, where Amy Gibbs spent a year, had no heating in the large, communal bathroom, hardly ideal for bathing dependent older, frail people, although the ward sister 'in charge of the ward for some years ... had no complaint about lack of warmth. ${ }^{46}$ This was alarming, considering that the HMC noted punishingly low ward temperatures at night, ${ }^{47}$ and Campbell remembered seeing urine frozen in a bed pan. Hospital hygiene was also poor. In 1965 the hospital suffered a typhoid outbreak (Anon. 1965). Typhoid spreads only in environments where human faeces or urine come into contact with food or drinking water. Campbell recalled 'a fairly strong smell, urine, faeces, or perhaps of disinfectant [and] when I went home at night I would feel the need to have a wash and totally change my clothes because it was all pervading'. ${ }^{48}$

Student nurse recruitment was difficult. Much nurse training comprised direct patient care on the wards, so nursing school underrecruitment meant understaffed wards, resulting in excessively busy trained staff and lack of teaching and supervision for students. Promising students were disenchanted by the training received at Friern, some preferring to become 
bus conductors. ${ }^{49}$ In 1951 the GNC noted a 'great wastage amongst female students': fifty of the sixty-eight who entered training in 1950 left within a year, ${ }^{50}$ significantly worse than the usual one third dropping out of training in general hospitals (Lyth 1988, p. 45). In 1963, the GNC inspected one geriatric ward with forty-five patients, average age eightyfour years, staffed during the day by one qualified nursing sister, three unqualified nursing assistants and one ward orderly. Nursing tasks included personal care, serving meals, washing up, cleaning and administration, so there was little time available to interact meaningfully with patients. Some practices were unsafe, such as dispensing medication from memory without referring to written prescription cards. ${ }^{51}$

In 1965, the HMC commissioned expert help to ascertain reasons for nursing shortages. Two surveys were undertaken, one on the 'female side' and another on the 'male side'. Miss Craig, a researcher from the King Edward's Hospital Fund (later, King's Fund, an independent charity working to improve health and care in England) asked nurses and doctors on twenty-three female wards why they thought the hospital was short of nursing staff. She was unaccompanied by senior staff, in whose presence juniors might have been unwilling to criticise, but it is unclear whether she spoke to nurses in groups or individually, which could also have affected their answers. Overall, discontent was common and mutual. Doctors criticised nurses for low standards, and nurses complained about lack of medical attention for patients on the back wards. Nurses disliked working on understaffed wards and those with poor facilities. Understaffing meant less attention for patients, who consequently stayed longer and increased the overcrowding, which made the hospital a less desirable place to work and undermined recruitment. Senior staff criticised 'The calibre of student nurses in mental hospitals to-day' who had no sense of ambition or vocation and who 'only come into hospital to have a roof over their heads and some money in their pockets', 52 a hostile attitude that would hardly entice them in.

The HMC feared that Craig's report, and a similar one on the male side, would generate unfavourable publicity, damage their reputation and further discourage recruitment. They therefore concealed the full reports, alleging that some conclusions were based on 'misapprehension or lack of knowledge of the situation ${ }^{53}$ or 'false information'. ${ }^{54}$ Deliberate distortion by independent researchers was unlikely, and the HMC did not reveal how they reached their conclusions. Condemning parts of the reports was easy compared to dealing with the problems. There is no evidence that the 
HMC used the reports constructively to exert pressure on the RHB to allocate more money or as tools to stimulate thought about how to reverse the trends.

A memorandum from the Ministry $(\mathrm{MoH} 1964, \mathrm{pp} .1-4)$ on improving psychiatric services recommended more outpatient clinics, day services and community resources and emphasised rehabilitation, with patients having suitable occupation, their own clothes and greater privacy and autonomy, such as deciding when to go to bed. It placed little emphasis on hospital buildings, in accordance with plans for closing them and moving services to DGHs and into the community. It also noted the gradually widening chasm between standards in the best and the worst psychiatric hospitals. It required HMCs to inform their RHBs about recent and proposed improvements. Most psychiatric hospitals within the North West Metropolitan region responded with patient-focused plans for therapy and rehabilitation. Friern HMC, however, outlined rudimentary needs:

Upgrading of existing lavatory and sanitary accommodation has been dealt with over the years, but new standards are constantly being set. In the 50 wards of this hospital there are no low level suites and the old fashioned type of chain-pull cistern continues to exist.... not in the bulk of the ward lavatories is there a washhand basin.... Half-doors to the lavatories have been replaced in many wards with a modern door. ${ }^{55}$

The HMC's grumble that 'new standards are constantly being set' gave the impression that it considered that making basic improvements was burdensome. The medical superintendent, Isaac Sutton, appeared indifferent to the inadequacies. Campbell contrasted him with Barton: 'Sutton was the absolute opposite, [wanted] the quiet life and didn't want to make any disruption or say boo to a goose really, and that was one of the big problems with Friern, why it lagged behind and didn't change. ${ }^{, 56}$ Apathy and resignation from Sutton and the HMC, and the 'vicious cycle where apathy hinders staff recruitment' were consistent with the hurdles to improvement that the memorandum envisaged in some hospitals $(\mathrm{MoH}$ 1964, p. 6). Barbara also detected Friern's fatalistic attitudes, when, early in her campaign, she spoke with HMC member Rose Hacker. Hacker doubted whether the recruitment cycle could be broken so Barbara informed her about hospitals where it had been. Hacker replied: 'It's all very well for them. They've all got really good senior medical staff. ${ }^{57}$ 


\section{Patients and Complaints at Friern}

Generally, patients in the 1960s accepted NHS care uncritically (Cartwright 1964, pp. 8, 203) but occasionally complaints reached the RHB and the Ministry. Examining complaints can shed light on standards of clinical practice and administrative procedures, such as how the authorities responded to the complainant and proposed to remedy the situation to avoid similar incidents in the future. At Friern, reports of good practice to balance against the complaints were not identified in archives or oral sources, although amid her criticisms, Barbara praised two helpful and empathetic ward sisters (Robb 1967, pp. 91, 102-103).

In April 1964, one complaint concerned an older man who sustained rib fractures while being looked after by nurses. His son, a senior academic at the University of London, wrote that the ward had a 'para-military atmosphere', that wearing clothes from a pool was depersonalising and that it was 'increasingly difficult [for staff] to treat people as individual human beings'. The staff were humane but the work atmosphere and environment were unacceptable. The complainant offered to talk to the HMC about his concerns rather "than weigh in on an undiscriminating public campaign'. ${ }^{58}$ The HMC minutes contain the written complaint but lack evidence of action to improve the situation. Perhaps pressure from a 'public campaign' might have achieved more.

Another complaint in 1964 related to alleged violence towards a patient named Bob. Staff told the family that he had fallen out of bed, but Bob's brother Fred noted that 'Bob would not tell me anything no matter how I tried to get it out of him but it looked to me that he had a wallop from somebody.' The family also complained about his belongings going missing, for which the staff blamed Bob: he was absentminded, left his belongings lying about or gave them away. ${ }^{59}$ The family was distraught about his ongoing care: 'no social life, no change of scene, just an overcrowded ward, unsuitable company, drugged and in bed by 7.30 to 8 o'clock every night, sometimes earlier. ${ }^{, 60}$ Bob's sister, Mrs Dickens, described him as 'a frightened crushed man due to the treatment he has received in this hospital'. She also described one occasion after she took him out and returned with him to the ward, that just after she left 'I heard my brother cry out "Leave go of my arm!" and then I looked through a slit in the side of a curtain on the ward door, and my brother was then pushed and was staggering along the corridor trying to keep his balance.' She reported this but received no adequate explanation. ${ }^{61}$ 
Mrs Dickens contacted the RHB. The Board replied that Bob's illness, rather than his care, was the cause of her unhappiness, that he experienced 'delusions and is apt to make up stories about imaginary happenings', and that the consultant thought his mental illness explained his allegations about being attacked by another patient. ${ }^{62}$ No change in his care took place in response to her letters. ${ }^{63}$ Negative responses stopped Mrs Dickens complaining: 'I dare not complain any more about anything as I have already been called a "Paranoid case". After Mrs Dickens involved her MP, the hospital offered to transfer Bob to Hill End Hospital, St Albans, within the same region, but inaccessible by public transport from where she lived in Muswell Hill. ${ }^{64}$ As Bob's only regular visitor, she refused the offer: she could not manage the thrity-mile round trip for each visit instead of the two-mile local bus ride.

Campbell recollected another complaint about a married middle-aged woman with multiple sclerosis who developed disturbed behaviour. She was put into a seclusion room that had a mattress on the floor and no heating. The family

kicked up a tremendous stink, which, I might say was reinforced by us as doctors. We were keen for them to kick up a stink with the superintendent at the time, MPs and everyone else, about these terrible conditions.... We saw it as a wedge in the door for getting things changed. ${ }^{65}$

The hospital authorities removed the patient to another institution. In Campbell's view, the hospital responded by: 'Sweeping it under the carpet... shift the problem onto somebody else. Back to the quiet life.'

In this small sample, the hospital authorities were evasive, blamed the complainant and the patient, and provided no convincing evidence that the criticisms were investigated or attempts made to remedy deficits. In two cases, the authorities aimed to appease the family by offering to move the patient to another hospital, with the effect of removing the complainant without dealing with the underlying causes that initiated their grievances.

\section{Comment}

A handful of psychiatrists, geriatricians and social scientists, beginning in the 1940s, demonstrated that older people's mental health and well-being could improve with better diagnosis, treatment, rehabilitation and social 
support. Many doctors overlooked this evidence, which contradicted established teaching and confounded stereotypical low expectations of well-being in old age. Compounding this, rigid hierarchical management in many psychiatric hospitals resisted change and punished staff who criticised disrespectful treatment and care regimes. In a few hospitals with dynamic and supportive leadership, therapeutic environments for older people began to emerge, but these innovative and effective models of psychiatric treatment and care were hardly replicated. Pressure for change in psychiatric hospitals from the antipsychiatry movement hardly touched older people, for whom, in the 1960s, lobbying was largely concerned with poverty, pensions, social welfare and employment rights, rather than with health (Thane 2010, pp. 13-14, 22).

Government plans and recommendations had the potential to improve services for older people, including Bevan's five-year plan to close the workhouses and improve community support, Guillebaud's proposal to spend more on services for older people, and Powell's long-term, timebound plans. However, recommendations for older people were permissive, lacked dedicated funding, clear lines of responsibility and sense of direction; and implementation was negligible in the broader context of competition for resources and NHS and welfare priorities. Older people and their families were frequently resigned to chronic impairment and decline with increasing age and rarely complained if services were inadequate. The Ministry used a simple economic plan of presumed cheapest provision for older people's custodial care, rather than genuinely exploring alternatives, in particular, that improving their health, preventing admission and enabling discharge might prove clinically possible, cheaper and more humane. In the twenty-first century, as in the 1960s, compared to services for younger people, older people's psychiatric provision lags behind, with inequitable allocation of revenue, despite evidence of benefit from interventions (Faculty 2011).

Friern's HMC swept complaints under the carpet and removed the need for the RHB or the Ministry to ask searching questions about the quality of services provided. An 'undiscriminating public campaign', which one complainant mentioned but did not undertake, might have had more impact than his private letter to the HMC, given the HMC's fear of negative publicity about their hospital and the broader lack of public, political and professional understanding of the psychiatric hospitals and what could be done to improve them. At Friern, little changed, but in November 1965, at 
the start of Barbara's campaign, the RHB informed the HMC that standards were inadequate and the hospital was under greater scrutiny than most. ${ }^{66}$

\section{Notes}

1. North West Metropolitan Regional Hospital Board (NWMRHB), Board meeting, 13 November 1967, 11 (London Metropolitan Archives, LMA).

2. Malcolm Campbell, interview by author, 2015 .

3. Figures are for England and Wales; New Southgate Group Hospital Management Committee (NSGHMC) minutes, 23 July 1964, 5799. At Friern, women over sixty occupied 60 percent of beds on the female side, one third of them age over seventy (LMA).

4. Others included TP Rees (Warlingham Park, Surrey) and Duncan Macmillan (Nottingham).

5. Robb, note of phone call with Rose Hacker, 1966, AEGIS/1/3 (AEGIS archive, London School of Economics).

6. Anne Shearer: journalist, including at the Guardian. Reported on Harperbury Hospital. Learning disability campaigner and Jungian analyst. Member of Davies Committee, 1971-1973. Interview by author, 2015.

7. Robb, citing NAMH newsletter, June 1965, AEGIS/1/4.

8. Final report, meeting, Robb and Tooth, 25 May 1965, AEGIS/1/1.

9. United Nations, Universal Declaration of Human Rights (1948). Article 5: 'No one shall be subjected to torture or to cruel, inhuman or degrading treatment or punishment.'

10. South West Thames Regional Health Authority, 'Report of Committee of Enquiry, St Augustine's Hospital, Chartham, Canterbury' 1976, typescript, 3-4 (Royal College of Psychiatrists Archives).

11. Anon psychiatrist, interview by author, 2016.

12. Memo, Abel-Smith to Mottershead, 'Report of working group on complaints procedures', 6 August 1969, 154/3/DH/46/1 (University of Warwick Modern Records Centre, UWMRC).

13. Letter, André Masters to Russell Barton, 12 December 1970, AEGIS/1/ $10 / \mathrm{B}$.

14. Blofeld, Ann. 1965. 'Report of the committee of inquiry on Friern Hospital' (Blofeld Report), 14. NWMRHB, Mental Health Committee, minutes and papers, 7 January 1966 (LMA).

15. An average of 17 percent across the region's psychiatric hospitals. NWMRHB, Mental Health Committee, minutes and papers, 18 March 1963, 5 (LMA).

16. Blofeld Report, 14.

17. Malcolm Campbell, interview by author, 2015 .

18. Meeting, Robb and Crossman, 12 November 1969, AEGIS/6/16. 
19. NSGHMC minutes, 23 July 1964, 5799 (LMA).

20. Malcolm Campbell, interview by author, 2015 .

21. David Enoch, Discussion, 26-27 in JC Barker, Mabel Miller, 'The problem of the chronic psychiatric patients', Shelton Hospital, post graduate education programme, 14 December 1967, AEGIS/2/3.

22. Similar to schizophrenia.

23. Brice Pitt, psychogeriatrician, interviewed by Margot Jefferys, 1991 (BLSA).

24. Crossman Diaries, September 1968 (Visit to Littlemore and Cowley Road hospitals) 152/JH/68/86-87 (UWMRC).

25. George Adams, geriatrician, interviewed by Anthea Holmes, 1991 (BLSA).

26. Phyllis Rowe, AEGIS meeting, 16 March 1967, 12, AEGIS/B/2.

27. Carrick McDonald, 'A rehabilitation programme for chronic psychogeriatric patients', 1977, 3 (Tom Arie's archives).

28. Russell Barton, interviewed by Diana Gittins, 1995, transcript, 14, WL/ GC/244/2/19 (Wellcome Library).

29. 'National Assistance Bill' Hansard HC Deb 24 November 1947, vol 444 cc.1603-1716.

30. 'Chronic Sick and Elderly (Services)' Hansard HC Deb 29 November 1957,578, cc.1443-1525.

31. Aneurin Bevan, 'NHS Control of Expenditure (England and Wales), Memorandum by the Minister of Health' 10 March 1950, 3, CAB129/ 38/31 (The National Archives, TNA).

32. 'Mentally Sick (Care and Accommodation)' Hansard HC Deb 19 February 1954,523 cc. $2293-2379$.

33. Memo, DS Todd-White to Dr Shaw, RHB (50)26, 29 April 1963, MH160/95 (TNA).

34. Information from David Jolley, 2015.

35. Memo, Geoffrey Tooth, 18 November 1964, 'Care of old people in hospitals and welfare homes', MH160/95 (TNA).

36. GNC, New Southgate: Friern Hospital, inspections 1948-1972, DT33/ 768 (TNA).

37. Malcolm Campbell, interview by author, 2015 .

38. Letter, Felix Post to secretary of Medical Committee, 13 October 1949, GPD31/49, MCD73/49 (Bethlem and Maudsley Hospital Archives).

39. GNC, Friern Hospital, March 1959, DT33/768 (TNA).

40. GNC, Friern Hospital, 1963, DT33/768 (TNA).

41. Blofeld Report, 4.

42. NSGHMC, agenda papers, 'Survey of bed accommodation at Friern Hospital with recommendations for the reduction of overcrowding to an acceptable level', November 1964 (LMA).

43. NWMRHB, mental health committee, minutes and papers, 26 April 1965 (LMA). 
44. NSGHMC, minutes, 26 March 1964, 5598 (LMA).

45. Friern joint consultative staffs committee, 11 June 1964, J1092 (LMA).

46. NSGHMC, minute book, 'Ward E3 - Bathroom Heating', 28 October 1965, 6266 (LMA); Robb, 'Record of a campaign' vol. 1, 3, Aegis/1/1; Many family houses did not have heating in the bedrooms or bathroom at this time.

47. NSGHMC, minutes, 27 February 1964, 5609 (LMA).

48. Malcolm Campbell, interview by author, 2015.

49. GNC, Friern Hospital, 20 February 1948, DT33/768 (TNA).

50. GNC, Friern Hospital, 1951, DT33/768 (TNA).

51. GNC, Friern Hospital, 1963, DT33/768 (TNA).

52. Miss Craig, 'Loss of nursing staff: Report of a small survey made in the female wards of Friern Hospital during the first week of January 1965', THC65/170, July 1965, NSGHMC, agenda papers (LMA).

53. NSGHMC, agenda papers, Doc65/11 (LMA).

54. NSGHMC, minute book, 28 October 1965, 6271 (LMA).

55. NWMRHB, mental health committee, minutes and papers, 'Plans drawn up by CH Pearsall' NSGHMC, 26 April 1965 (LMA).

56. Malcolm Campbell, interview by author, 2015 .

57. Robb, notes of phone call with Rose Hacker, 1966, AEGIS/1/3.

58. Letter, RP to NSGHMC, agenda papers HMC 64/58, 21 April 1964 (LMA).

59. Letter, undated, Fred to Mrs Dickens, AEGIS/4/1.

60. Letter, Dickens to MoH, I September 1967; Letter, Dickens to Robb, 5 March 1968, AEGIS/4/1/A.

61. Letter, Dickens to Kenneth Robinson, July 1967, AEGIS/4/1.

62. Letter, BS Lord, NWMRHB, to Dickens, 24 September 1964, AEGIS/4/ $1 / \mathrm{A}$.

63. Letter, Dickens to MoH, 1 September 1967; Letter, Dickens to Robb, 5 March 1968, AEGIS/4/1/A.

64. Letter, Hugh Rossi to Dickens, 27 July 1967, AEGIS/4/1.

65. Malcolm Campbell, interview by author, 2015 .

66. Letter, G Weston, RHB, to CH Pearsall, NSGHMC, Doc 65/110, 12 November 1965 (LMA).

\section{BiBLIOGRAPHY}

Altschul, Annie. 1957. Aids to Psychiatric Nursing. London: Baillière, Tindall and Cox.

Anderson, William Ferguson. 1956. 'Difficulties in the management of sick old people'. Medical Press, 236, 341-345. 
Anon. 1954. 'Helping the elderly and the confused to carry on: year's success at an Oxford Day Hospital'. Guardian, 15 January.

Anon. 1965. 'Eleven typhoid suspects in London'. Times, 2 September.

Barham, Peter. 1997. Closing the Asylum: The Mental Patient in Modern Society. London: Penguin Books.

Barton, Russell. 1959. Institutional Neurosis. Bristol: John Wright and Sons.

Barton, Russell. 1967. 'Foreword' ix-xi. In Robb, 1967.

Batt, JC. 1949. 'Confusional mental states'. Medical Press, 222, 15-18.

Bergmann, Klaus. 2009. In The Development of Old Age Psychiatry in Britain 1960-1989, (Guthrie Trust Witness Seminar 2008) ed. Claire Hilton. http:// www.gla.ac.uk, accessed 18 September 2016.

Beveridge, William. 1942. Social Insurance and Allied Services. Cmd. 6404. London: HMSO.

Bickford, J. 1955. 'The forgotten patient. (i). The problem reviewed'. Lancet, ii, 917-919.

British Medical Association. 1947. The Care and Treatment of the Elderly and Infirm. London: BMA.

Brooke, Eileen. 1967. A Census of Patients in Psychiatric Beds 1963. London: HMSO.

Brooks, Jane. 2009. “"The geriatric hospital felt like a backwater”: aspects of older people's nursing in Britain, 1955-1980'. Journal of Clinical Nursing, 18, 2764-2772.

Brothwood, John. 1971. 'The organisation and development of services for the aged with special reference to the mentally ill' 99-112. In Recent Developments in Psychogeriatrics: A Symposium, ed. David Kay and Alexander Walk. London: RMPA.

Carse, Joshua. Panton, Nydia and Watt, Alexander. 1958. 'A district mental health service: the Worthing experiment'. Lancet, i, 39-4l.

Cartwright, Ann. 1964. Human Relations and Hospital Care. London: Routledge and Kegan Paul.

Cohen, Gerda. 1964. What's Wrong with Hospitals? Harmondsworth: Penguin Books.

Committee on the Economic and Financial Problems of the Provision for Old Age. Cmd. 9333. (Phillips Report) 1954. London: HMSO.

Cook, Leslie. Dax, Eric Cunningham and Maclay, Walter. 1952. 'The geriatric problem in mental hospitals'. Lancet, i, 377-382.

Denham, Michael. 2004. 'The history of geriatric medicine and hospital care of the elderly in England between 1929 and the 1970s'. PhD thesis, University College London. http://www.discovery.ucl.ac.uk, accessed 17 September 2016.

DHSS. 1971. Report of the Farleigh Hospital Committee of Inquiry. Cmnd. 4557. London: HMSO. 
DHSS. 1972. Annual Report of the Hospital Advisory Service to the Secretary of State for Social Services and the Secretary of State for Wales for the Year 1971. London: HMSO.

Dickinson, Tommy. 2015. 'Curing Queers': Mental Nurses and Their Patients, 1935-1974. Manchester: Manchester University Press.

Faculty of the Psychiatry of Old Age, General and Community Psychiatry Faculty. 2011. The Equality Act 2010 and Adult Mental Health Services: Achieving NonDiscriminatory Age-Appropriate Services. Occasional Paper OP82. London: RCPsych.

Gibson, Ronald. 1957. 'The care of the elderly in general practice'. Research Newsletter, 4, 99-114.

Goffman, Erving. 1961. Asylums: Essays on the Social Situation of Mental Patients and Other Inmates. New York: Anchor Books.

Goffman, Erving. 1963. Stigma: Notes on the Management of Spoiled Identity. New York: Simon and Schuster.

Guillebaud Report. See Ministry of Health 1956.

Gulland, Anne. 2014. 'Ronald Arthur "Sam" Robinson'. BMJ, 348, g3581.

Harvey, Audrey. 1965. The unknown prisoners'. Guardian, 10 August.

Hilton, Claire. 2007. 'Felix Post (1913-2001) pioneer in the psychiatry of old age'. Journal of Medical Biography, 15, 31-36.

Hilton, Claire. 2014. 'Joint geriatric and old age psychiatric wards in the United Kingdom, 1940s - early 1990s: a historical study'. International Journal of Geriatric Psychiatry, 29, 1071-1078.

Hilton, Claire. 2016. 'Psychogeriatrics in England in the 1950s': greater knowledge with little impact on provision of services'. History of Psychiatry, 27, 3-20.

Howell, Trevor. 1951. 'The problem of the chronic sick'. Medical Press, 225, 505-507.

Hunter, Richard and Macalpine, Ida. 1974. Psychiatry for the Poor: 1851 Colney Hatch Asylum - Friern Hospital 1973: A Medical and Social History. London: Dawson of Pall Mall.

Jolley, David. 2003. 'Remembering Russell Barton'. BJPsych Bulletin, 27, 233-234.

Jones, Kathleen 1993. Asylums and After. London: Athlone Press.

Jones, Kathleen and Fowles, AJ. 1984. Ideas on Institutions. London: Routledge and Kegan Paul.

Jones, Kathleen and Sidebotham, Roy. 1962. Mental Hospitals at Work. London: Routledge and Kegan Paul.

Kay, David. Beamish, Pamela and Roth, Martin. 1957. 'Some medical and social characteristics of elderly people under state care'. Sociological Review Monograph, 5, 173-193.

Kay, David. Beamish, Pamela and Roth, Martin. 1964a. 'Old age mental disorders in Newcastle upon Tyne: a study of prevalence'. British Journal of Psychiatry, $110,146-158$. 
Kay, David. Beamish, Pamela and Roth, Martin. 1964b. 'Old age mental disorders in Newcastle upon Tyne: a study of possible social and medical causes'. British Journal of Psychiatry, 110, 668-682.

Kidd, Cecil. 1962a. "Rejection of the seventh age": society and the aged sick'. Almoner, 14, 452-457.

Kidd, Cecil. 1962b. 'Misplacement of the elderly in hospital: a study of patients admitted to geriatric and mental hospitals'. BMJ, ii, 1491-1495.

Kingston, Frank. 1963. 'The demands for psychiatric beds'. Lancet, i, 107-108.

Kirkpatrick, WJA. 1967. 'Conscience and commitment' 48-57. In Robb 1967.

Laing, RD and Esterson, Aaron. 1964. Sanity, Madness and the Family. London: Penguin Books.

Lewis, Aubrey. 1946. 'Ageing and senility: a major problem of psychiatry'. British Journal of Psychiatry, 92, 150-170.

Lewis, Aubrey and Goldschmidt, Helen. 1943. 'Social causes for admission to a mental hospital for the aged'. Sociological Review, 35, 86-98.

Lowther, CP and Williamson, James. 1966. 'Old people and their relatives'. Lancet, ii, 1459-1460.

Lyth, Isabel Menzies. 1988. 'Social systems as a defence against anxiety' 43-88. In Containing Anxiety in Institutions: Selected Essays. Vol. 1, ed. Isabel Menzies Lyth. London: Free Association Books.

Macmillan, Duncan. 1960. 'Preventive geriatrics'. Lancet, ii, 1439-1441.

Mandelbrote, Bertram. 1964. 'Mental illness in hospital and community: development and outcome' 267-290. In Problems and Progress in Medical Care, ed. Gordon McLachan. London: Nuffield Provincial Hospitals Trust, OUP.

Martin, Denis. 1962. Adventure in Psychiatry. Oxford: Bruno Cassirer.

Mass Observation. 1948. 'Old Age'. Mass Observation Bulletin, OctoberNovember, 21, 1-4.

Mayer-Gross, Willy. 1945. 'Electric convulsion treatment in patients over 60'. British Journal of Psychiatry, 91, 101-103.

Means, Robin and Smith, Randall. 1985. The Development of Welfare Services for Elderly People. Kent: Croom Helm.

Ministry of Health. 1950a. Care of the Aged Suffering from Mental Infirmity. HMC (50)25.

Ministry of Health. 1950b. Treatment of the Elderly Chronic Sick. HMC (50)38.

Ministry of Health. 1956. Report of the Committee of Enquiry Into the Cost of the National Health Service. Cmd. 9663. (Guillebaud Report). London: HMSO.

Ministry of Health. 1957. Survey of Services Available to the Chronic Sick and Elderly 1954-1955. Boucher Report. London: HMSO.

Ministry of Health. 1961. Report for the Year 1960. Part II: On the State of the Public Health. Cmnd. 1550. London: HMSO. 
Ministry of Health. 1962. A Hospital Plan for England and Wales. Cmnd. 1604. London: HMSO.

Ministry of Health. 1963. Health and Welfare: The Development of Community Care: Plans for the Health and Welfare Services of the Local Authorities in England and Wales. Cmnd. 1973. London: HMSO.

Ministry of Health. 1964. Improving the Effectiveness of Hospitals for the Mentally Ill. HM (64)45. London: HMSO.

Ministry of Health. 1965. Care of the Elderly in Hospitals and Residential Homes. HM (65)77. London: HMSO.

Ministry of Health. 1966. Handbook for Members of Hospital Management Committees. London: HMSO.

Ministry of Health. 1968a. Findings and Recommendations Following Enquiries Into Allegations Concerning the Care of Elderly Patients in Certain Hospitals. Cmnd. 3687. London: HMSO.

Ministry of Health. 1968b. The Activities of Psychiatric Hospitals: A Regional Comparison. Mental Hospitals and Units 1964. Statistical Report Series no. 3. London: HMSO.

Ministry of Health. 1968c. Psychiatric Nursing Today and Tomorrow: Report of the Joint Sub-committee of the Standing Mental Health and the Standing Nursing Advisory Committees. London: HMSO.

National Old People's Welfare Council. 1958. Notes on Mental Frailty in the Elderly. London: National Council of Social Services.

Nolan, Peter. 1995. 'The development of mental health nursing' 1-18. In Stress and Coping in Mental Health Nursing, ed. Jerome Carson, Leonard Fagin and Susan Ritter. London: Chapman and Hall.

Norton, Doreen. 1956. 'The place of geriatric nursing in training'. Nursing Times, 6 July, 621-624.

Norton, Doreen. 1988. The Age of Old Age. London: Scutari Press.

Phillips Committee. See Committee on the Economic and Financial Problems.

Pitt, Brice. 1968. 'Attempting to solve staffing problems' 29-30. In Improving the Effectiveness of Hospitals and Services for the Mentally Ill and Mentally Subnormal: A Collection of Papers Presented at Conferences Held at the Hospital Centre in 1966 and 1967, ed. Anthony Whitehead and D. Cortazzi. London: King's Fund.

Political and Economic Planning. 1948. Population Policy in Great Britain. London: PEP.

Post, Felix. 1944. 'Some problems arising from a study of mental patients over the age of 60 years'. British Journal of Psychiatry, 90, 554-565.

Powell, Enoch. 1961. 'Opening speech' ('Water Tower') 5-10. In Emerging Patterns for the Mental Health Services and the Public: Proceedings of a Conference at Church House Westminster, 9-10 March 1961. London: NAMH.

Robb, Barbara. 1967. Sans Everything: A Case to Answer. London: Nelson. 
Robinson, Ronald 'Sam'. 1965. 'The organisation of a diagnostic and treatment unit for the aged in a mental hospital' 186-205. In Psychiatric Disorders in the Aged, ed. World Psychiatric Association. Manchester: Geigy.

Robinson, Ronald 'Sam'. 2009. In The Development of Old Age Psychiatry in Britain 1960-1989, (Guthrie Trust Witness Seminar 2008) ed. Claire Hilton. http://www.gla.ac.uk, accessed 18 September 2016.

Rogers, Anne and Pilgrim, David. 1996. Mental Health Policy in Britain: A Critical Introduction. Basingstoke: Macmillan Press.

Roth, Martin. 1955. 'The natural history of mental disorders in old age'. British Journal of Psychiatry, 101, 281-230.

Rowntree, B. Seebohm. 1947. Old People: Report of a Survey Committee on the Problems of Ageing and the Care of Old People. London: Nuffield Foundation.

Royal Commission on Population 1949. Cmd. 7695. London: HMSO.

Sheldon, Joseph. 1948. The Social Medicine of Old Age. London: OUP.

Strabolgi. 1965. 'Dumping ground for the aged'. Catholic Herald, 19 November.

Taylor, Stephen. 1954. Good General Practice. London: OUP.

Thane, Pat. 1990. "The debate on the declining birth-rate in Britain" the "menace" of an ageing population, 1920s-1950s'. Continuity and Change, $5,283-305$.

Thane, Pat. 2000. Old Age in English History: Past Experiences, Present Issues. Oxford: OUP.

Thane, Pat. 2010. 'Older people and equality' 7-28. In Unequal Britain, ed. Pat Thane. London: Continuum.

Thomson, A. 1950. 'Discussion on the problems of old age'. Proceedings of the Royal Society of Medicine, 43, 929-933.

Thomson, W. 1959. 'The elderly who live alone'. Medical Press, 242, 477-480.

Townsend, Peter. Cited in Anon. 1961. 'Old people's welfare services'. Almoner, 14,379 .

Townsend, Peter. 1962. The Last Refuge. London: Routledge and Kegan Paul.

Townsend, Peter. 1965. 'A national survey of old people in psychiatric and nonpsychiatric hospitals, residential homes, and nursing homes' 223-232. In Psychiatric Hospital Care: A Symposium, ed. Hugh Freeman. London: Baillière, Tindall and Cassell.

Townsend, Peter. 1973. The Social Minority. London: Allen Lane.

Warren. Marjory. 1943. 'Care of chronic sick'. BMJ, ii, 822-823.

Watts, Cuthbert and Watts, Beatrice. 1952. Psychiatry in General Practice. London: J and A Churchill.

Webster, Charles. 1991a. 'The elderly and the early National Health Service' 165193. In Life and Death and the Elderly, ed. M. Pelling and R. Smith. London: Routledge.

Webster, Charles. 1991b. 'Psychiatry and the early National Health Service: the role of the Mental Health Standing Advisory Committee' 103-116. In 150 
Years of British Psychiatry 1841-1991, ed. German Berrios and Hugh Freeman. London: Gaskell.

Webster, Charles. 1998. The National Health Service: A Political History. Oxford: OUP.

Welshman, John. 1996. "“Growing old in the city": public health and the elderly in Leicester 1948-74'. Medical History, 40, 74-89.

Whitehead, Anthony. 1965. 'A comprehensive psychogeriatric service'. Lancet, ii, 583-586.

Whitehead, Anthony. 1970. In the Service of Old Age: The Welfare of Psychogeriatric Patients. Harmondsworth: Penguin Books.

Whitehead, Tony. cited in: Anon. 1974. 'Aged "could be spared misery". Guardian, 7 October.

Williamson, James. Stokoe, I.H. Gray, S. and Fisher, M. 1964. 'Old people at home: their unreported needs' Lancet, i, 1117-1120.

Winn, Merrick. 1955. 'Britain's shame'. Daily Express, 19 September.

World Health Organisation. 1959. Mental Health Problems of Aging and the Aged. Geneva: WHO.

Open Access This chapter is licensed under the terms of the Creative Commons Attribution 4.0 International License (http://creativecommons.org/licenses/ by $/ 4.0 /$ ), which permits use, sharing, adaptation, distribution and reproduction in any medium or format, as long as you give appropriate credit to the original author(s) and the source, provide a link to the Creative Commons license and indicate if changes were made.

The images or other third party material in this chapter are included in the book's Creative Commons license, unless indicated otherwise in a credit line to the material. If material is not included in the book's Creative Commons license and your intended use is not permitted by statutory regulation or exceeds the permitted use, you will need to obtain permission directly from the copyright holder.

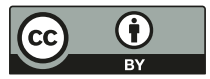

